\title{
A Case for Silicon Fertilization to Improve Crop Yields in Tropical Soils
}

\author{
V. D. Meena - M. L. Dotaniya $\cdot$ Vassanda Coumar \\ S. Rajendiran $\cdot$ Ajay $\cdot$ S. Kundu $\cdot$ A. Subba Rao
}

Received: 30 May 2013/Revised: 23 October 2013/Accepted: 31 October 2013/Published online: 25 December 2013

(C) The Author(s) 2013. This article is published with open access at Springerlink.com

\begin{abstract}
Long period of intensive crop cultivation deplete the available soil silicon (Si). Depletion of available $\mathrm{Si}$ in the soil could be one of the possible limiting factors amongst others contributing to declining yields. The lower values for $\mathrm{Si}$ in the soil can be justified due to (i) severe and frequent soil erosion and sediment transportation. (ii) Usually plants absorb $\mathrm{Si}$ almost equal to the concentration of most of macronutrients. (iii) Due to the desilication process, $\mathrm{Si}$ in the soil is continuously lost as the result of leaching process. Subtropical and tropical soils are generally low in available $\mathrm{Si}$ and would benefit from $\mathrm{Si}$ fertilization. The silicon content in some regions might be limited to sustainable crop production. Hence, improved $\mathrm{Si}$ management to increase yield and sustain crop productivity appears to be necessary in temperate as well in tropical countries. In order to address this problem of yield decline or stagnation, it seems necessary to survey the Si status of
\end{abstract}

\author{
V. D. Meena $(\bowtie) \cdot$ M. L. Dotaniya · V. Coumar . \\ S. Rajendiran - Ajay - S. Kundu - A. Subba Rao \\ Division of ESS, Indian Institute of Soil Science, Nabib Bagh, \\ Berasia Road, Bhopal, MP 462 038, India \\ e-mail: vasu_maheshin84@rediffmail.com \\ M. L. Dotaniya \\ e-mail: mohan30682@gmail.com \\ V. Coumar \\ e-mail: mvcoumar@iiss.ernet.in \\ S. Rajendiran \\ e-mail: rajanselladurai@yahoo.co.in \\ Ajay \\ e-mail: ajay@iiss.ernet.in \\ S. Kundu \\ e-mail: skundu@iiss.ernet.in \\ A. Subba Rao \\ e-mail: asrao_iiss@yahoo.co.in
}

agriculturally important soils of different parts of the country and develop region-specific integrated nutrient management systems that include the Si element.

Keywords Biotic and abiotic stress $\cdot$ Silica .

Stress tolerance $\cdot$ Resistance $\cdot$ Yield

\section{Introduction}

Farmers are intensifying land use without proper nutrient management practices which results in depletion of nutrients from soil, which is linked to yield decline. According to a recent hypothesis, the yield decline is associated with a decrease in the effective $\mathrm{N}$ supply from soil although total soil $\mathrm{N}$ remains unchanged [1]. However, another possibility that could be contributing to the overall decline in yield might be the lack of or depletion of plant-available Si. The exogenous application of $\mathrm{Si}$ is not routine with the belief, that the soil itself can sustain its supply. Unfortunately the silica that occurs in soil is in an unavailable polymerized form and for its absorption by plants it has to be depolymerized and rendered soluble by means of biological or chemical reactions in the soil. Further, the silicon removed from world arable soils is estimated to the tune of 210-224 million tons annually (FAO estimate). The need for proper Si management to increase yield and sustain crop productivity appears to be necessary in temperate as well in tropical countries. In addition, the Si diminution in the soil can occur in intensive cultivation practices and continuous monoculture of high-yielding cultivars. As a result, these soils are generally low in available Si. Rice and sugarcane grown in rotation on organic and sandy soils have shown positive responses to pre-plant applications of calcium silicate slag [2]. 
Silicon is the second most abundant constituent in the earth's crust [3]. It constitutes $27.7 \%$ of the total weight in soil after the oxygen (47\%) [4]. It ranges from 200 to $300 \mathrm{~g} \mathrm{Si} \mathrm{Kg}^{-1}$ in clay soil and $450 \mathrm{~g} \mathrm{Si} \mathrm{kg}^{-1}$ in sandy soils $[5,6]$. Its content in soil varies from $<1$ to $45 \%$ by dry weight [7]. The traditional practice of collecting the ashes from the back yard of houses supplies not only potash but also silicon. Silicon is an agronomically important fertilizer element that enhances plant tolerance to abiotic stresses [8]. Silicon fertilizer has a double effect on the soil-plant system as under. (i) Improved plant-silicon nutrition reinforces plant-protective properties against diseases, insect attack, and unfavorable climatic conditions. (ii) Soil treatment with biogeochemically active silicon substances optimizes soil fertility through improved water, physical and chemical soil properties, and maintenance of nutrients in plant-available forms.

\section{Plant Absorption of Silicon}

Plants absorb silicon from the soil solution in the form of monosilicic acid, also called orthosilicic acid $\left[\mathrm{H}_{4} \mathrm{SiO}_{4}\right]$. The largest amount of silicon is absorbed by sugarcane (300-700 $\mathrm{kg}$ of $\mathrm{Si} \mathrm{ha}^{-1}$ ), followed by rice (150-300 $\mathrm{kg}$ of $\left.\mathrm{Si} \mathrm{ha}{ }^{-1}\right)$, and wheat (50-150 kg of $\left.\mathrm{Si} \mathrm{ha}^{-1}\right)$ [9]. On an average, plants absorb from 50 to $200 \mathrm{~kg}$ of Si ha ${ }^{-1}$. Such values of absorbed silicon cannot be fully explained by passive absorption (such as diffusion or mass flow) because the upper $20 \mathrm{~cm}$ soil layer contains only an average of $0.1-1.6 \mathrm{~kg} \mathrm{Si} \mathrm{ha}{ }^{-1}$ as monosilicic acid [10, 11]. Results have shown that rice roots possess specific ability to concentrate silicon from the external solution [12]. Yoshida [13] revealed that rice plant absorbs silica in the form of ortho-silicic acid $\left(\mathrm{H}_{4} \mathrm{SiO}_{4}\right.$ or $\left.\mathrm{Si}(\mathrm{OH})_{4}\right)$ along with water from the growing medium and the water is lost through transpiration. Because of continued absorption and transpiration, the $\mathrm{Si}$ concentration increases and at higher levels ortho-silicic acid polymerizes into silica gel $\left(\mathrm{SiO}_{2} \cdot \mathrm{nH}_{2} \mathrm{O}\right)$ through a non-enzymatic reaction. There are three classes of silicon absorbers i.e. (a) $\mathrm{Si}$ accumulator crops (rice, wheat, millet, sugarcane) as they require large quantity of silicon, (b) Si non-accumulator-Snapdragon (Antirrhinum majus) and (c) Si excluder (soybean) [14, 15].

\section{Silicon Transport in Plants}

In the plant, silicon is transported from the root to shoot by the transportation stream in the xylem (Fig. 1). Soluble monosilicic acid may penetrate through cell membranes passively. After root adsorption, monosilicic acid is translocated rapidly into the leaves of the plant in the transpiration stream [16]. Silicon is concentrated in the epidermal tissue as a fine layer of silicon-cellulose membrane and is associated with pectin and calcium ions. By this means, the double-cuticular layer can protect and mechanically strengthen plant structures. With increasing Si concentration in the plant sap, monosilicic acid is polymerized. The chemical nature of polymerized silicon has been identified as silicon gel or biogenic opal, amorphous $\mathrm{SiO}_{2}$, which is hydrated with water molecules. Monosilicic acid polymerization is assigned to the type of condensable polymerization with gradual dehydration of monosilicic acid and then polysilicic acid.

Plants synthesize silicon-rich structures of nanometric (molecular), microscopic (ultrastructural), and macroscopic (bulk) dimensions. $90 \%$ of absorbed silicon is transformed into various types of phytoliths or silicon-cellulose structures, represented by amorphous silica. Partly biogenic silica is generated as unique cell or inter-cell structures at the nanometer level [17]. The chemical composition of oat (Avena sativa L.) phytoliths (solid particles of $\mathrm{SiO}_{2}$ ) comprises amorphous silica (82-86\%) and varying amounts of sodium, potassium, calcium and iron [18].

\section{Silicon Content of Plant}

The content of silica in plants is equivalent to or more than the major nutrients $\mathrm{N}, \mathrm{P}, \mathrm{K}$ supplied through fertilizers. Higher plants differ characteristically in their capacity to take up silicon [20]. Some plants absorb more silica than they require and this gets deposited on tissues as it cannot be excreted [21]. Depending on their $\mathrm{SiO}_{2}$ content [expressed as a percentage of shoot dry weight (SDW)], they can be divided into three major groups: wetland Gramineae, such as wetland rice or horsetails (Equisetum), 10-15\%; dryland Gramineae, such as sugarcane and most of the cereal species and a few dicotyledons, 1-3\%; and most dicotyledons, especially legumes, $<0.5 \%$ [22]. Among the plants, silica concentration is found to be higher in monocotyledons than in dicotyledons and its level shows an increase from legumes $<$ fruit crops $<$ vegetables $<$ grasses $<$ grain crops [23]. The aerial plant parts accumulate more $\mathrm{Si}$ than roots. In general the Si content of shoots tend to decline in following order; liver worts $>$ horse tails $>$ club mosses $>$ mosses $>$ angiosperms $>$ gymnosperms $>$ ferns [24]. Grasses accumulate 2-20\% foliar dry weight as hydrated polymer or silica gel. Rice accumulates 4-20\% $\mathrm{Si}$ in straw and almost every part contains this element which is not at all added exogenously as fertilizer as done with nitrogen, phosphorus and potassium, the trinity of nutrients. In rice leaf blades $90 \%$ or more of silicic acid exists as silica gel (polysilicic acid) and $0.5 \%$ as low molecular weight silicic acids (largely composed of orthosilicic acid). It was found that silica content of rice plant increased with the age of the crop from transplanting to harvest [25]. The silica content of rice straw at harvest 


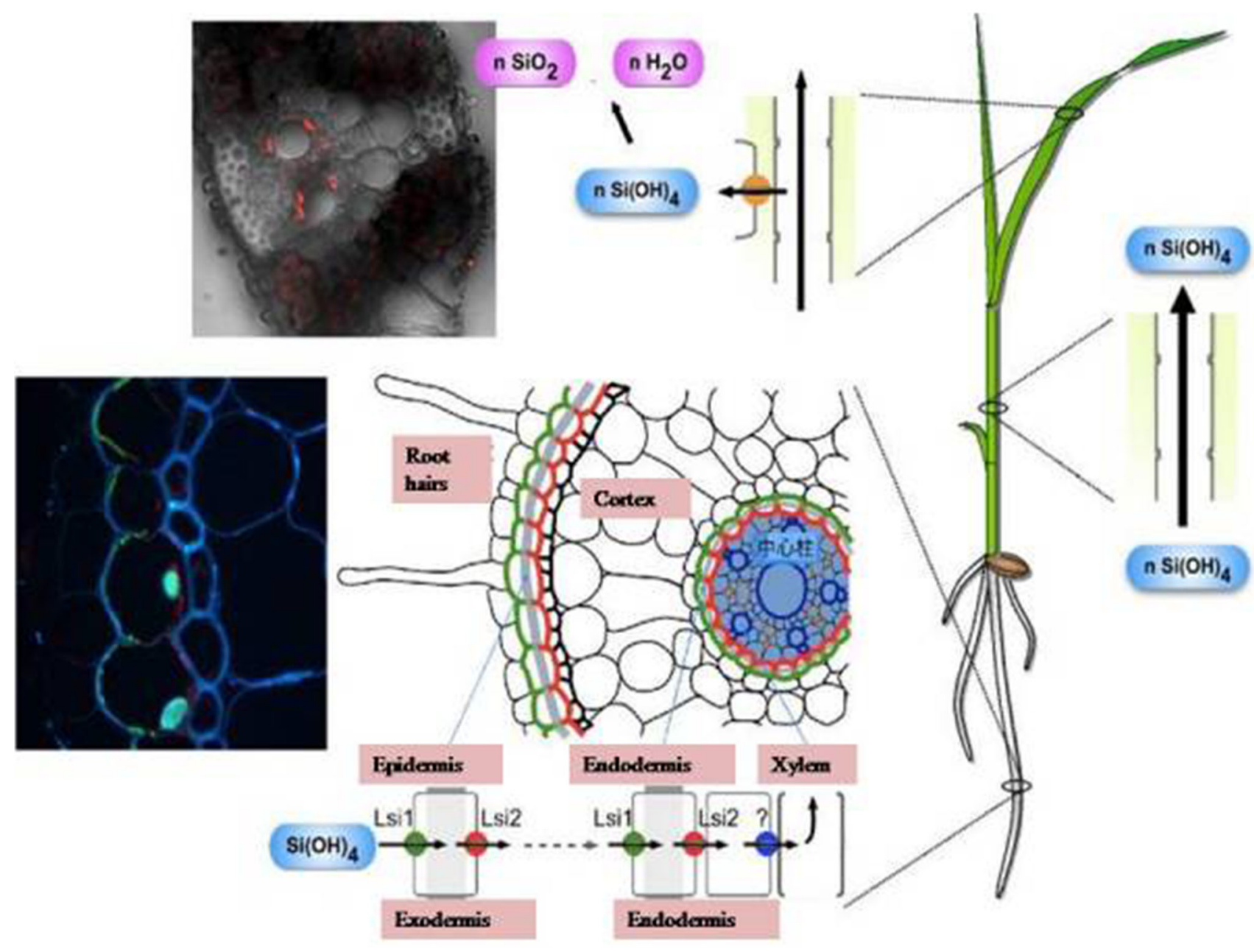

Fig. 1 Silicon transporters involved in the uptake and distribution of Si in rice [19]

ranged from 4.8 to $13.5 \%$ in the dry season and from 4.3 to $10.3 \%$ in the wet season [26]. It is estimated that a 12 month old sugarcane crop accumulates about $380 \mathrm{~kg} \mathrm{Si} /$ ha [27]. Leaf analysis can be a useful indicator of Si status, and optimum growth requires minimum leaf tissue concentration of $0.6 \% \mathrm{Si}$ [28]. Sugar yield was optimal with a leaf concentration of $\geq 0.60 \% \mathrm{Si}$. A recent survey of Florida sugarcane fields determined that estimated $25 \%$ of organic soils had production losses $>10 \%$ due to insufficient leaf Si concentration [29]. Plants take up different quantities of silica according to their species [30]. Rice, oat, rye and wheat, seed coat accumulate most of the silica and grain the least [31]. It was observed that the leaves and stems of maize and sorghum and the leaves of sugarcane and bamboo had highest silica than other plant parts. Ishizuka reported that silica content of rice straw ranged from 4 to $20 \%$ with an average of $11 \%$ [32]. Plants of the family Poaceae, Equisetaceae and Cyperaceae exhibit high silicon accumulation ( $>4 \% \mathrm{Si}$ ), the Cucurbitales, Uritcales and Commellinaceae show intermediate levels $(2-4 \% \mathrm{Si})$ while most other species contain less silicon $(<2 \% \mathrm{Si})$. The mean relative silicon content of certain plant species are given in Table 1.

Table $1 \mathrm{Si}\left(\mathrm{SiO}_{2}\right)$ concentration of different plant species [33]

\begin{tabular}{ll}
\hline Crop & $\mathrm{SiO}_{2}(\%)$ \\
\hline Barley & 1.92 \\
Rye & 1.58 \\
Red clover & 0.12 \\
Blue lupin & 0.24 \\
Oats & 2.04 \\
Rye & 2.41 \\
Rye grass & 2.34 \\
Crimson clover & 0.12 \\
Peas & 0.25 \\
Mustard & 0.15 \\
Rice & $1.5-8.0$ \\
\hline
\end{tabular}


Table 2 Silicon concentration in food crops [34, 35]

\begin{tabular}{lc}
\hline Food & $\mathrm{mg} \mathrm{Si} / 100 \mathrm{~g}$ \\
\hline Chickpea & 0.76 \\
Soybean & 1.19 \\
Lentils (red boiled) & 4.42 \\
Spinach (fresh/boiled) & 5.12 \\
Wheat bran & 10.98 \\
Grapes & 0.49 \\
Mango & 2.00 \\
Banana raw & 4.77 \\
Dates dried & 16.61 \\
\hline
\end{tabular}

Table 3 Silicon sources used to augment soil $\mathrm{Si}$ or include $\mathrm{Si}$ in nutrient solutions

\begin{tabular}{lll}
\hline Si source & Chemical formula & Si content (\%) \\
\hline Salicic acid & $\mathrm{H}_{4} \mathrm{SiO}_{4}$ & 29 \\
Calcium silicate slag & - & $18-21$ \\
Calcium silicate & $\mathrm{CaSiO}_{3}$ & 24 \\
Potassium silicate & $\mathrm{K}_{2} \mathrm{SiO}_{3}$ & 18 \\
Sodium silicate & $\mathrm{Na}_{2} \mathrm{SiO}_{3}$ & 23 \\
Quartz sand (fine grind) & $\mathrm{SiO}_{2}$ & 46 \\
Amorphus silica & $\mathrm{ASi}$ & - \\
\hline
\end{tabular}

Plant products are relatively higher in silicon content than meat and meat products. The food as well as fruits consumed by man or animals are not free from silicon and contain varying levels of silicon. Water, vegetables, fruits, milk and milk products contain varying levels of silicon. The Si concentration of some of the food and fruit crops is given in Table 2.

\section{Silicon Sources Used to Augment Soil Si}

Although silicon is a very abundant element, for a material to be useful as a fertilizer, it must have a relatively high content of silicon, provide sufficient water-soluble silicon to meet the needs of the plant, be cost effective, have a physical nature that facilitates storage and application, and not contains substances that will contaminate the soil [36]. Many potential sources meet the first requirement (Table 3); however, only a few meet all of these requirements. Crop residues, especially of silicon-accumulating plants such as rice, are used as silicon sources. However, the crop demand for application of Si fertilizer generally exceeds that which can be supplied by crop residues. Inorganic materials such as quartz, clays, micas, and feldspars, although rich in $\mathrm{Si}$, are poor silicon-fertilizer sources because of the low solubility of the Si. Calcium
Table 4 Suppression of neck blast in rice due to silicon application (1,000 kg Si/ha) [39]

\begin{tabular}{lll}
\hline $\mathrm{Si}(\mathrm{kg} / \mathrm{ha})^{\mathrm{a}}$ & Neck blast incidence $(\%)$ & Yield $(\mathrm{kg} / \mathrm{ha})$ \\
\hline 0 & 72 & 2,284 \\
1,000 & 44 & 3,445 \\
\hline
\end{tabular}

${ }^{a} \mathrm{Si}$ as calcium silicate

silicate, obtained as a byproduct of steel and phosphorus production, is one of the most widely used silicon fertilizer. Potassium silicate, though expensive, is highly soluble and can be used in hydroponic culture. Other sources that have been used commercially are calcium silicate hydrate, silica gel, and thermo-phosphate [36].

Silicon alleviates certain nutritional disorders like akiochi or bronzing. Liang et al. [37] strongly suggested that Si may be involved in metabolic or physiological and/or structural activity in higher plants exposed to abiotic and biotic stresses.

\section{Effect on Biotic Stresses}

The $\mathrm{Si}$ in plants is found to alleviate many biotic and abiotic stresses, leading to the application of silicates either directly to crops or incorporate it into the fertilizers applied. It does not form a constituent of any cellular component but is primarily deposited on the walls of the epidermis and vascular tissues conferring strength, rigidity and resistance to pests and diseases. The effect of Si on plant resistance to pests is considered to be due to accumulation of absorbed $\mathrm{Si}$ in the epidermal tissue or expression of pathogensis-induced host-defense responses. Accumulated monosilicic acid polymerizes into polysilicic acid and then transforms to amorphous silica, which forms a thickened silicon-cellulose membrane and which gets associated with pectin and calcium ions. By this means, a double-cuticular layer protects and mechanically strengthens plants. Silicon might also form complexes with organic compounds in the cell walls of epidermal cells, therefore increasing their resistance to degradation by enzymes released by the rice blast fungus (Magnaporthe grisea M.E. Barr). Si gets associated with lignin-carbohydrate complexes in the cell wall of epidermal cells [38]. It is found to suppress the activity of certain enzymes particularly invertase, resulted in greater sucrose production in sugarcane and the reduction in phosphatase provided a greater supply of essential high energy precursors needed for optimum growth.

\section{Effect on Disease Resistance and Suppression}

The mechanism for $\mathrm{Si}$-induced resistance to diseases is due to (i) $\mathrm{Si}$ acting as a physical barrier and (ii) soluble $\mathrm{Si}$ 
Table 5 Diseases suppressed by Si nutrition

\begin{tabular}{llll}
\hline Crops & Disease & Pathogen & References \\
\hline Rice & Leaf and neck blast & Pyricularia oryzae & {$[40]$} \\
& Brown spot & Bipolaris oryzae & {$[41]$} \\
& Sheat blight & Rhizoctonia solani & {$[41]$} \\
& Leaf scald & Gerlachia oryzae & {$[40]$} \\
& Grain discoloration & Bipolaris fusarium & {$[40]$} \\
& Stem rot & Sclerotium oryzae & {$[42]$} \\
Sugarcane & Sugar rust & Puccinia melanocephala & {$[43]$} \\
& Ring spot & Leptosphaeria Sacchari & \\
& & Phyllosticta sp. (anamorph) & \\
Banana & Panama wilt & Fusarium oxysporium f. sp. cubense & {$[45,46]$} \\
Grape & Powdery mildew & Uncinela necator, Oidium tuckeri \\
Cucumber & Powdery mildew & Sphaerotheca fuliginea, Pythium. \\
Wheat & Powdery mildew & Erysiphe graminis, Oidium monilioides & {$[47]$} \\
Cowpea & Rust & Uromyces phaeseoli typia Arth. \\
Cucumber & Root disease & Pythium ultimum \\
Barley & Powdery mildew & Erysiphe graminis \\
Pea & Leaf spot & Mycosphaerella pinodes \\
\hline
\end{tabular}

acting as a modulator of host resistance to pathogens. Silicon is deposited beneath the cuticle to form a cuticle-Si double layer which mechanically impede penetration of fungi and thus disrupt the infection process. Application of silicate silicon at $1,000 \mathrm{~kg} / \mathrm{ha}$ reduced neck blast by $30.5 \%$ over the control (Table 4).

Silicon nutrition suppressed the leaf and neck blast, brown spot, sheath blight, leaf scald, grain coloration, stem rot, bacterial leaf blight and root knot nematode infection in rice and many other diseases in different crops (Table 5).

A research team in Florida headed by Lawrence Datnoff demonstrated the effectiveness of $\mathrm{Si}$ enrichment in controlling several diseases of warm-season turfgrasses. About $30 \%$ of gray leaf spot on St. augustine grass was controlled by $\mathrm{Si}$ applications, and its addition increased the effectiveness of fungicide treatments [53]. Common bermuda grass exhibited a doubling of $\mathrm{Si}$ content when its growth medium was supplemented with calcium silicate [54]. In bermuda grass, leaf spot caused by Bipolaris cynodontis was suppressed up to $40 \%$ by the application of $\mathrm{Si}$. This study demonstrated that addition of $\mathrm{Si}$ can increase the disease tolerance.

Silicon stimulates chitinase activity and rapid activation of peroxidases and polyphenoxidases after fungal infection [55]. Glycosidically bound phenolics extracted from $\mathrm{Si}$ amended plants when subjected to acid or B-glucosidase hydrolysis displayed strong fungistatic activity. Dann and Muir [52] reported that pea (Pisum sativum L.) seedlings amended with potassium silicate increased the activity of chitinase and B-1,3-glucanase against the fungal blight caused by Mycosphaerella pinodes. In addition, fewer lesions were observed on leaves from silicon-treated pea seedlings than on leaves from pea seedlings not amended with silicon.

\section{Effect on Plant Insect and Pests}

The deposition of silica on epidermal layers offers a physical barrier to insects. Sucking pests and leaf eating caterpillars have a low preference for the silicified plant tissues. The incidences of stem maggots, green leaf hopper, brown plant hopper and white backed plant hopper, leaf folder etc. in rice were reduced due to Si nutrition. Use of ash in the home to control aphids is an old age practice in rural India. Application of Si to corn affected the infection of the Spodoptera. In wheat and sorghum silicon negatively affected the preference and reduced reproduction rates of the green bug Schizophis graminum (Table 6).

Rice with low tissue $\mathrm{Si}$ is associated with increased susceptibility to insect pests and fungal diseases as well as increased problems with crop lodging [56]. White fly (Bemisia tabaci) is an important pest of cucumber, cotton, sugarcane etc. Its excreted honey dew leads to the formation of sooty moulds which reduces photoreception mechanically and thus reduces the yield. Both soil and foliar application of $\mathrm{Si}$ as calcium silicate increased the mortality by nymphs of white fly.

In 2002, Chinese researcher, Chang [70] revealed that Si fertilizer can shorten the leaf lesion caused by bacterial leaf blight by 5-22\%. Reducing the size of lesions is directly proportional to the reduction of soluble sugar in the leaves due to the presence of silicon. Application of $200 \mathrm{~kg}$ silica ha ${ }^{-1}$ 
Table 6 Pest suppressed by $\mathrm{Si}$ nutrition

\begin{tabular}{|c|c|c|c|}
\hline Crops & Pest & Scientific name & References \\
\hline \multirow[t]{8}{*}{ Rice } & Stem maggot & Chlorops oryzae & {$[56]$} \\
\hline & Green leaf hopper & Nephotettix bipunctatus & {$[57]$} \\
\hline & Brown plant hopper & Nilaparvata lugens & {$[58]$} \\
\hline & White backed plant hopper & Sogetella furcitera & {$[59]$} \\
\hline & Leaf spider & Tetranychus spp. & {$[13]$} \\
\hline & Stem borer & Chilo suppressalis & {$[60]$} \\
\hline & Grey garden slug & Deroceras reticula tum & {$[61]$} \\
\hline & Mites & - & {$[62]$} \\
\hline \multirow[t]{2}{*}{ Wheat } & Green bug & Scizaphis graminum & {$[63]$} \\
\hline & Red flour beetle & Tribotium castaneum & {$[64]$} \\
\hline Sorghum & Green bug & Scizaphis graminum & {$[65]$} \\
\hline \multirow[t]{2}{*}{ Corn } & Leaf aphid & Rhopalosiphum maidis & {$[66]$} \\
\hline & Borer & Sesamia calamistis & {$[64]$} \\
\hline \multirow[t]{2}{*}{ Sugarcane } & Stalk borer & Eldana saccharina & {$[67]$} \\
\hline & Stem borer & Diatraea saccharina & {$[68]$} \\
\hline Grape & Fruit cracking & - & [69] \\
\hline
\end{tabular}

can reduce the infection of dirty panicle (grain discoloration) by as much as $18 \%$ and increases rice yield by $20 \%$. Chinese scientists reported that when the available $\mathrm{SiO}_{2}$ in soil is increased from 60 to $220 \mathrm{ppm}$, the silicon content in flag leaf increased correspondingly from 7.4 to $18.7 \%$. Meanwhile the neck rot infection was observed to be reduced from 8.6 to $1.5 \%$ while pink stem borer infection was reduced from 33.6 to $6.6 \%$.

\section{Effect on Abiotic Stresses}

Silicon nutrition alleviates many abiotic stresses including physical stress like lodging, drought, radiation, high temperature, freezing, UV and chemical stress like salt, metal toxicity, nutrient imbalance and many others [27]. It increases drought tolerance in plants by maintaining plant water balance, photosynthetic efficiency, erectness of the leaves and structure of xylem vessels under high transpiration rates due to higher temperature and moisture stress [71]. The beneficial effects are attributed to Si deposition in the cell walls of roots, leaves, culms and hulls. Silicon deposits in cell walls of xylem vessels prevent compression of the vessels under conditions of high transpiration caused by drought or heat stress. The silicon cellulose membrane in epidermal tissue protects plants against excessive loss of water by transpiration. This action occurs owing to a reduction in the diameter of stomatal pores and, consequently, a reduction in leaf transpiration. The Si deposition in roots reduces the binding sites for metals resulting in decreased uptake and translocation of salts and toxic metals from roots to shoot. There are several hypotheses to combat abiotic stresses viz., (a) improved photosynthetic activity, (b) enhanced $\mathrm{K} / \mathrm{Na}$ selectivity ratio, (c) increased enzyme
Table 7 Role of $\mathrm{Si}$ in mitigation of/alleviating the abiotic stress in plants

\begin{tabular}{lll}
\hline Abiotic stress & Crops & References \\
\hline $\begin{array}{l}\text { Physical stress } \\
\text { Lodging }\end{array}$ & All crops & {$[72]$} \\
Drought & & \\
Radiation & & \\
High temperature & & \\
Freezing & & \\
UV etc. & & \\
Chemical stress & & {$[73]$} \\
Salinity & Rice & {$[74]$} \\
& Wheat & {$[75]$} \\
& Mesquite & {$[76,77]$} \\
Mn toxicity & Bean & {$[78]$} \\
Al toxicity & Rice & {$[80]$} \\
Fe toxicity & Leaf freckle in sugarcane \\
Cd toxicity & Wheat, Rice, Maize & \\
\hline
\end{tabular}

activity, and (d) increased concentration of soluble substances in the xylem, resulting in limited sodium adsorption by plants. Si alleviated effects have been associated with an increase in antioxidant defense mechanism of plants (Table 7). There are various types of mechanisms within the plants to alleviate different stresses (Fig. 2).

Silicon deposited in the plant tissues helps to alleviate water stress by decreasing transpiration and improves light interception characteristics by keeping the leaf blade erect [82]. Accumulation of Si will form a thick silicated layer on the leaf surface which effectively reduces cuticular transpiration. The findings from Japanese researchers 


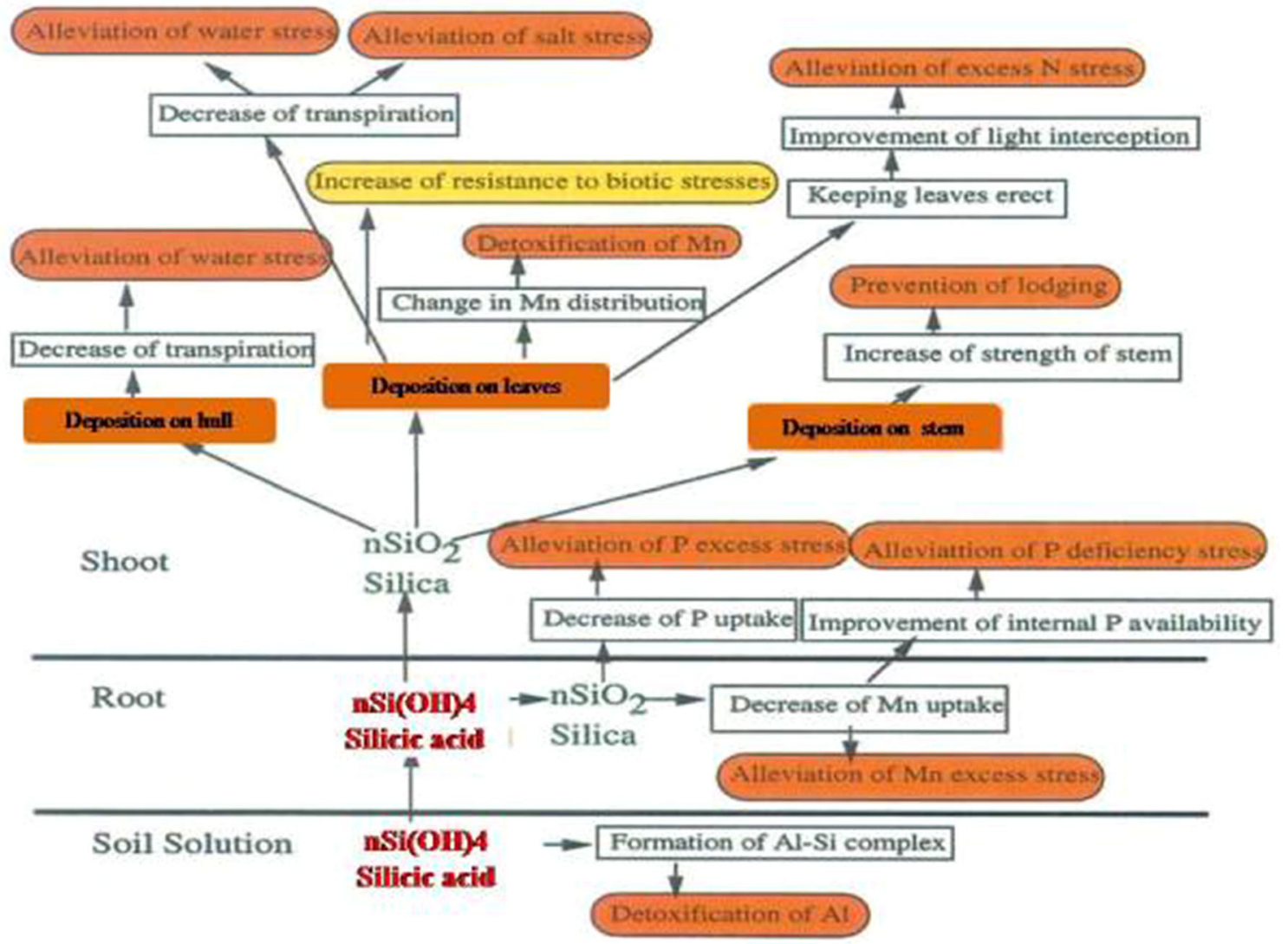

Fig. 2 Beneficial effects of Si under various stresses [81]

revealed that the application of silica will reduce transpiration loss by as much as $30 \%$. A well-thickened layer of silica gel associated with the cellulose in the epidermal cell walls, which reduces water loss, while an epidermal cell wall with less silica gel will allow water to escape at an accelerated rate [83]. Kaya et al. [84] reported that inhibition of plant growth was significantly alleviated by $\mathrm{Si}$ supplement. Under water stress, Si significantly increased the dry weight of shoots and total biomass of maize (Table 8). Lux et al. [85] noted that $\mathrm{Si}$ application increased growth of Sorghum bicolor, grown under water stress. Water stress tends to increase biomass partitioning to roots, increasing root: shoot ratio [86]. It reduces leaf concentration of calcium $(\mathrm{Ca})$ and potassium $(\mathrm{K})$ in maize plants, but the addition of Si increases these nutrient levels; $\mathrm{Ca}$ level remains normal in well watered conditions under the high-Si treatment, but $\mathrm{K}$ was lower. It was also suggested that silica in plants filter harmful ultraviolet radiation reaching leaf surface, acting as 'windows' [87]. Silicon can also alleviate imbalances between zinc and phosphorus supply. Silicon supply increases the photo assimilation of carbon and also promotes the assimilated carbon to the panicle in rice [88]. It is probably the only element which is able to enhance the resistance to multiple stresses. The mechanism of such protection is due to $\mathrm{Si}$ binding with metals and preventing their concentration to toxic levels at localized sites. Iron, manganese and aluminum are the metals most often found to be less toxic in the presence of $\mathrm{Si}$. In Si-accumulator plants, iron and manganese are immobilized within the roots before they can be transported to shoots [89]. This is enhanced in wetland plants because $\mathrm{Si}$ increases the rigidity and volume of aerenchyma (airfilled spaces in roots and shoots) that favours the transport of oxygen into the roots, oxidizing iron and manganese into their less toxic form. In case of non-accumulator plants, $\mathrm{Si}$ can suppress the transport of metals to shoots by forming complexes with the metals in root cell walls. Some nutrient elements like calcium can also be immobilized in this way.

Gong et al. [90] reported that application of $\mathrm{Si}$ can increase dry matter (DM) of wheat in well watered conditions and improve the growth under drought conditions by maintaining high leaf area. It insures high assimilatory capability, thickening leaves which are beneficial to reduce the transpiration loss of water. Therefore, application of $\mathrm{Si}$ may be an available pathway to increase production of wheat crop in arid or semi arid areas. Silicon did not change the relative water content (RWC) and water 
Table 8 Effect of Si on RWC; total shoot and RDWs; and root:shoot ratio of maize plants grown under water stress [84]

\begin{tabular}{llllll}
\hline Treatments & RWC $(\%)$ & g/plant & & Root:shoot ratio \\
\cline { 3 - 6 } & & Total DW & Shoot DW & Root DW \\
\hline WW & $75.3 \mathrm{a}$ & $3.26 \mathrm{a}$ & $2.92 \mathrm{a}$ & $0.32 \mathrm{ab}$ & $0.110 \mathrm{~d}$ \\
$\mathrm{WW}+\mathrm{Si} 1$ & $74.3 \mathrm{a}$ & $3.23 \mathrm{a}$ & $2.90 \mathrm{a}$ & $0.33 \mathrm{a}$ & $0.113 \mathrm{~d}$ \\
$\mathrm{WW}+\mathrm{Si} 2$ & $76.4 \mathrm{a}$ & $3.25 \mathrm{a}$ & $2.94 \mathrm{a}$ & $0.31 \mathrm{a}$ & $0.105 \mathrm{~d}$ \\
WS & $42.9 \mathrm{c}$ & $1.65 \mathrm{~d}$ & $1.36 \mathrm{~d}$ & $0.29 \mathrm{~b}$ & $0.213 \mathrm{a}$ \\
WS+Si1 & $62.5 \mathrm{~b}$ & $2.08 \mathrm{c}$ & $1.78 \mathrm{c}$ & $0.30 \mathrm{ab}$ & $0.168 \mathrm{~b}$ \\
WS+Si2 & $69.4 \mathrm{~b}$ & $2.39 \mathrm{~b}$ & $2.08 \mathrm{~b}$ & $0.31 \mathrm{ab}$ & $0.149 \mathrm{c}$ \\
\hline
\end{tabular}

$W W$ well watered, WS water stressed, $\mathrm{Sil} 1 \mathrm{mM}$, Si2 $2 \mathrm{mM} \mathrm{Si}$ as $\mathrm{Na}_{2} \mathrm{SiO}_{3}$ in nutrient solution

Values followed by different small letters, in the same column, are significantly different at $P \leq 0.05$

potential without drought stress. But drought stress decreased them, and they were higher in the presence of added Si than absence (Table 9). Therefore, Si application could improve the water status under drought conditions. The leaf area was also significantly increased by $\mathrm{Si}$ in the well-watered conditions. Silicon application improved water economy and DM yield of wheat [90].

\section{Effects on Morphological Characters of the Plant}

Silicon is reported to accumulate in the plant body of various crops like rice that enables the plants to tolerate the drought stress. The response of crops to silicon application in rice and sugarcane have been extensively investigated both in solution and soil culture [91-93]. Silicon tends to maintain erectness of rice leaves and clumps there by increasing the photosynthesis because of better light interception.

In a study done by Gong et al. [90] it was found that wheat plants grown in pots with silicon applied before sowing had greater plant height, leaf area, and dry materials as compared to those without $\mathrm{Si}$ applied in well watering conditions. In the stress conditions, plants grown in Si-applied soil could maintain higher RWC, water potential and leaf area as compared to those without $\mathrm{Si}$ applied. Moreover, the Si applied plant dry materials were not significantly changed by drought while those of plants grown in pots without $\mathrm{Si}$ were significantly decreased, and this was mainly due to growth inhibition of the shoots. Drought stressed wheat growing in pots with Si applied had a significantly greater leaf weight ratio and lower specific leaf area compared to those of stressed plants in the absence of applied Si. This demonstrates that the leaves of stressed plants growing in pots with applied $\mathrm{Si}$ were thicker as compared to those without Si. This may have a beneficial effect by reducing the transpirational loss of water and maintain high RWC and water potential.

With the increase of Si levels, the dry weight of the plant will increase together with its height and number of tillers [94]. It increases leaf area which enhanced photosynthetic rate and prevent the destruction of chlorophyll (Tables 10, 11). Effects of potassium silicate on the morphological characters were more at tillering stage in rice as compared to sodium silicate. The studies found that the addition of $\mathrm{Si}$ in nutrient solution increased the $\mathrm{Si}$ and $\mathrm{Ca}$ concentrations in the leaves as well as in roots [84]. The Si treatments largely improved the total DM, chlorophyll content, and RWC and proline accumulation. An increase in DM and growth rate of wheat crop was reported by silicon application under drought stress conditions [95]. Si nutrition improves the light-receiving posture of the plants, thereby stimulating photosynthate production in plants [96]. It also plays an important role in phosphorus nutrition having an interrelationship with phosphorus [97]. The role of exogenous application of siliceous materials to rice and sugarcane and their responses varied with the soil type [91, 98].

Table 9 Effect of Si on plant height, RWC, water potential, and leaf area under drought condition [90]

\begin{tabular}{lllll}
\hline Treatments & Plant height $(\mathrm{cm})$ & RWC $(\%)$ & Water potential $(\mathrm{MPa})$ & Leaf area $\left(\mathrm{cm}^{2}\right)$ \\
\hline $\mathrm{CK}$ & $25.3 \pm 2.2 \mathrm{a}$ & $89.5 \pm 1.0 \mathrm{a}$ & $0.59 \pm 0.06 \mathrm{a}$ & $35.4 \pm 2.4 \mathrm{a}$ \\
$\mathrm{DR}$ & $23.3 \pm 2.4 \mathrm{a}$ & $82.8 \pm 1.3 \mathrm{~b}$ & $1.40 \pm 0.05 \mathrm{~b}$ & $26.8 \pm 1.3 \mathrm{~b}$ \\
$\mathrm{Si}$ & $31.9 \pm 2.2 \mathrm{~b}$ & $90.3 \pm 0.8 \mathrm{a}$ & $0.58 \pm 0.03 \mathrm{a}$ & $45.2 \pm 2.3 \mathrm{c}$ \\
$\mathrm{DR}+\mathrm{Si}$ & $23.5 \pm 1.2 \mathrm{a}$ & $85.5 \pm 1.3 \mathrm{c}$ & $1.00 \pm 0.07 \mathrm{c}$ & $35.1 \pm 5.5 \mathrm{a}$ \\
\hline
\end{tabular}

$C K$ control, $D R$ drought condition

Means $( \pm \mathrm{SE}$ ) followed by different letters are significantly different at the $P \leq 0.05$ level according to $T$ test 
Table 10 Effects of sodium silicate on morphological characters of rice at tillering stage [94]

\begin{tabular}{lllllll}
\hline $\begin{array}{l}\text { Silicon } \\
\text { concentration } \\
(\mathrm{ppm})\end{array}$ & $\begin{array}{l}\text { Plant } \\
\text { height } \\
(\mathrm{cm})\end{array}$ & $\begin{array}{l}\text { Tiller } \\
(\text { No. })\end{array}$ & $\begin{array}{l}\text { Leaf area } \\
\left(\mathrm{cm}^{2} / \mathrm{hill}\right)\end{array}$ & \multicolumn{2}{c}{ Dry weight } & (g/hill) \\
\hline 0 & $68.05 \mathrm{a}$ & $12.55 \mathrm{~b}$ & $571.58 \mathrm{~b}$ & $3.41 \mathrm{a}$ & $2.44 \mathrm{a}$ & $5.85 \mathrm{a}$ \\
50 & $68.50 \mathrm{a}$ & $14.55 \mathrm{a}$ & $625.96 \mathrm{a}$ & $3.41 \mathrm{a}$ & $2.58 \mathrm{a}$ & $6 \mathrm{a}$ \\
100 & $70.27 \mathrm{a}$ & $14.77 \mathrm{a}$ & $659.82 \mathrm{a}$ & $4.06 \mathrm{a}$ & $2.76 \mathrm{a}$ & $6.83 \mathrm{a}$ \\
\hline
\end{tabular}

Means followed by different letter (within a column) are significantly different at 0.05 probability level according to DMRT

Table 11 Effects of potassium silicate on morphological characters of rice at tillering stage [94]

\begin{tabular}{lllllll}
\hline $\begin{array}{l}\text { Silicon } \\
\text { concentration } \\
(\mathrm{ppm})\end{array}$ & $\begin{array}{l}\text { Plant } \\
\text { height } \\
(\mathrm{cm})\end{array}$ & $\begin{array}{l}\text { Tiller } \\
(\text { No. })\end{array}$ & $\begin{array}{l}\text { Leaf area } \\
\left(\mathrm{cm}^{2} / \mathrm{hill}\right)\end{array}$ & \multicolumn{2}{l}{ Dry weight $(\mathrm{g} / \mathrm{hill})$} \\
\cline { 5 - 8 } & & & & Stem & Leaf & Total \\
50 & $69.33 \mathrm{~b}$ & $11.77 \mathrm{~b}$ & $591.11 \mathrm{a}$ & $4.07 \mathrm{a}$ & $2.76 \mathrm{a}$ & $6.84 \mathrm{a}$ \\
100 & $71.77 \mathrm{a}$ & $12.88 \mathrm{a}$ & $617.91 \mathrm{a}$ & $4.22 \mathrm{a}$ & $2.96 \mathrm{a}$ & $7.18 \mathrm{a}$ \\
& $73.11 \mathrm{a}$ & $13.55 \mathrm{a}$ & $639.37 \mathrm{a}$ & $4.91 \mathrm{a}$ & $3.15 \mathrm{a}$ & $8.06 \mathrm{a}$ \\
\hline
\end{tabular}

Means followed by different letter (within a column) are significantly different at 0.05 probability level according to DMRT

Optimization of Si nutrition increases mass and volume of roots, increasing total and adsorbing surfaces [99, 100]. Application of silicon fertilizer increases the dry weight of barley by 21 and $54 \%$ over 20 and 30 days of growth, respectively, relative to plants receiving no supplemental silicon [101]. Silicon fertilizer increases root respiration [102]. A germination experiment with citrus (Citrus spp.) has demonstrated that with increasing monosilicic acid concentration in irrigation water, the weight of roots increased more than that of shoots [103]. The same effect was observed for bahia grass (Paspalum notatum Flügge) [104].

\section{Effect on Crop Yield}

Silicon fertilizers are applied to crops in several countries for increased productivity and sustainable production. It was found beneficial to barley, wheat, corn, sugarcane, cucumber, citrus, tomato and other crops [27]. Several studies have suggested positive growth effects of silicon nutrition, increased biomass, yield and pollination [105]. Application of Si improves growth of maize and increases its production and yield in arid or semi-arid areas under water-stress conditions [84]. Mukhtar et al. [106] revealed that silicon nutrition has significant effect on crop growth, physiological attributes and yield parameters. The effect was more significant for wheat variety Chakwal-50 under $10 \% \mathrm{Si}$ application with irrigation as compared to other genotypes under other levels of $\mathrm{Si}$ concentrations. It boosted up crop growth and accumulation of more photoassimilates from source to sink and consequently, it led to higher grain yield. Ahmed et al. [107] found that the increase in silicon leads to increase in leaf area index (LAI), specific leaf weight, chlorophyll content (SPAD), leaf dry weight (LDW), SDW, root dry weight (RDW), total dry weight (TDW) and remarkable decrease in leaf water potential and shoot to root ratio in sorghum cultivars as compared to control treatment. When silicon concentration is applied with irrigation LAI, SPAD, LDW, SDW, RDW, TDW, net assimilation rate, relative growth rate, leaf area ratio and water use efficiency increased by 30,31 , $40,30,28,30,27,35,32,30$ and $36 \%$ respectively as compared to water deficient treatment. These results suggest that silicon application may be useful to improve the drought tolerance of sorghum through the enhancement of water uptake ability. Mukkram et al. [108] also found Si increased growth and yield due to decreased $\mathrm{Na}^{+}$uptake in wheat under salt stress. Abro et al. [109] in wheat crop reported that, when silicic acid was applied at $0.25-0.50 \%$ level as fertilizer, the rate of germination was increased; while if its level exceeded this limit, the germination rate and yield was reduced. Hence, it is suggested that $\mathrm{Si}$ in lesser amounts can be beneficial in increasing grain yield and growth of cereal crops. Singh et al. [110] reported that $180 \mathrm{~kg} \mathrm{ha}^{-1}$ of $\mathrm{Si}$ increases $\mathrm{N}$ and $\mathrm{P}$ content in grain and straw of rice which results in increased DM and yield.

Due to a synergistic effect, applied Si has the potential to raise the optimum rate of $\mathrm{N}$, thus helping to enhance yields [42]. Raid et al. [111] reported an average increase of $20 \%$ in sugarcane yield by the Ca silicate application at 3 tons/acre. Its application benefited both crops in a ricesugarcane rotation when applied prior to rice planting [112]. Sugarcane yield responses to Ca silicate application ranged from 0 to 9 tons sugar/acre/year with relative yield being reduced to as much as $23 \%$ without application [113]. Research findings from China revealed that rice yield of $7.5 \mathrm{t} / \mathrm{ha}$ require $750-1,500 \mathrm{~kg} \mathrm{ha}^{-1}$ of silica. On an average, $1,125 \mathrm{~kg} \mathrm{ha}^{-1}$ of silica is required to achieve that yield. This far exceeds the absorption of the three major plant nutrients namely nitrogen, phosphorous, and potassium. Application of $\mathrm{Si}$ in rice increased the grain yield under both upland and water logged conditions [114]. The application of silicate augmented its absorption by rice plant other nutrients as well. With adequate Si the uptake of nitrogen was increased $[115,116]$. However, decrease in $\mathrm{N}$ content was also reported in rice in response to $\mathrm{Si}$ addition to solution culture [77, 117]. Greenhouse and field experiments showed benefits of $\mathrm{Si}$ fertilization for rice, barley, wheat, corn, sugarcane, cucumber, tomato, citrus and other crops [82].

Silicon plays an important role in hull formation in rice and grain quality [118]. The hulls of poor-quality, milky- 
white grains (kernels) are generally low in Si content, which is directly proportional to the Si concentration in the rice straw [119]. Studies at IRRI indicate that Si deficiency always reduces the number of panicles per square meter and percentage of filled grains [120]. Barley grains that were harvested from a silicon-fertilized plot had better capacity for germination than grains from no silicon fertilizer applied plots [121]. Poor Si nutrition had a negative effect on tomato (Lycopersicon esculentum Mill.) flowering [122]. It is important to note that the application of $\mathrm{Si}$ fertilizer accelerated citrus growth by $30-80 \%$, speeded up fruit maturation by $2-4$ weeks, and increased fruit quantity [123]. A similar acceleration in plant maturation with $\mathrm{Si}$ fertilizer application was observed for corn [121]. Sorghum accumulates silica in the form of phytoliths. It enhances the crop quality, yield, growth and protects the plant from various biotic and abiotic hurdles [124].

\section{New Silicon Fertilization Strategies (Bio-augmentation and Nano-particles)}

Unlike conventional fertilizers, Si fertilizers are available only in limited quantities and often are too expensive for most farmers to afford. Supplemental Si has been provided to be beneficial when silica concentration falls below $1 \%$ in straw and to avoid this problem $\mathrm{Si}$ bearing materials have been recommended for field application [87]. Although it is not possible to recycle all $\mathrm{Si}$ removed by crops, serious recycling will help to mitigate the problem of soil Si depletion, thus reducing Si fertilization requirements. It is to be noted that rice farmers in the Cauvery delta in India regularly apply 3-5 tones river sand $\left(\mathrm{SiO}_{2}\right)$ per hectare once in 2-4 years. It is presumed that sand loosens the heavy clay but in reality it restores the silicon removed from soil by continuous mono-culturing of rice. Some recent significant strategies are as under.

1. Recycling of organic siliceous materials: application of organic siliceous materials like straw, husk and husk ash enhanced root and shoot length, plant height, total as well as productive tillers per hill, filled grains and 1000 grain weight in rice. As rice leaf and stem generally contains 5-6\% (ranges from 2 to $10 \%$ ) Si, and rice husk contains $10 \%$, thus returning the crop residues back to the soil will help to replenish $\mathrm{Si}$ in the soil [32, 91, 98]. The most suitable time of $\mathrm{Si}$ application in rice is about 60 days before harvesting.

2. Addition of silicate amendments: Application of potassium, magnesium and calcium silicate increases the rice yield. On an average 10-30 \% increased yields were recorded through silicate amendments [36].

3. Application of nanotechnology: In recent years, the application of nanotechnology has led to the production of granulated and liquid silicon fertilizer with high bio-availability. This new Si fertilizer can easily penetrate the leaf and form a thick silicate layer on leaf surface. IRRI research indicates that $\mathrm{Si}$ deficiency can be rectified by the application of calcium silicate slag at the rate of $120-200 \mathrm{~kg} \mathrm{ha}^{-1}$ or potassium silicate at $40-60 \mathrm{~kg} \mathrm{ha}^{-1}$ [120].

4. Phytoliths that are located mainly in shoots of monocots return to the soil through litterfall if the plants are not harvested and contribute to the biogeochemical cycle of $\mathrm{Si}$. According to recent progress made on the understanding of the biogeochemical cycle of $\mathrm{Si}$ and the weathering process of silicate minerals, phytoliths may significantly contribute to the resupply of Si to plants. The authors suggest that straw of crops, which contains large amounts of phytoliths, should be recycled in order to limit the depletion of soil bioavailable Si.

5. Inoculation of silicate solubilizing bacteria (SSB) with organic siliceous materials recorded further enhancement.

\section{Silica Solubilizing Bacteria}

Improvement of plant growth and crop yield by liberating the soil nutrients through seed bacterization and soil application of biofertilizers are practiced by farmers all over the world $[125,126]$. The solubilization of silica by bacteria is considered as a source of supply for crops. Soil contains a variety of micro organisms but a few are capable of solubilizing silicates. Several microbes like Bacillus caldolytyicus, Bacillus mucilaginosus var siliceous, Proteus mirabilis, Pseudomonas and Penicillium were found to release silica from natural silicates [127, 128].

A virulent SSB was isolated and tested on a variety of crops in different soils. Inoculation of SSB was found to release soluble silica in soils and also from silicate minerals. This bacterium is used as a bio-fertilizer and found to enhance the growth, suppresses pest and diseases and increase the crop yield. A Bacillus species was isolated from granite crusher yard soil and upon inoculation this SSB to rice increased the biomass and grain yield. In soil incubation studies with four different soils found that SSB inoculation released silicon and concurrently released phosphorus and potassium. It was suggested that besides silicon, silicate minerals contain potassium, calcium, magnesium, iron and zinc and therefore inoculation of SSB to soil may benefit the crop by releasing several of these nutrients [129, 130]. Soil incubation studies revealed that inoculation of SSB to sterile and unsterile soil solubilized silica in water and enhanced the available silica in soils (Tables 12, 13).

Field trials conducted with SSB showed that this bacterium enhanced the growth, chlorophyll content, 1,000 grain 
Table 12 Available silica (mg/L) in water from different soils inoculated with SSB [129]

\begin{tabular}{|c|c|c|c|c|c|c|c|}
\hline \multirow[t]{2}{*}{ S. No. } & \multirow[t]{2}{*}{ Treatments } & \multicolumn{2}{|c|}{ Red soil } & \multicolumn{2}{|c|}{ Clay soil } & \multicolumn{2}{|l|}{ Sand } \\
\hline & & Initial & After 4 weeks & Initial & After 4 weeks & Initial & After 4 weeks \\
\hline 1 & Sterile soil & 203 & 210 & 119 & 215 & 173 & 176 \\
\hline 2 & Sterile soil + SSB & 302 & 321 & 278 & 326 & 258 & 330 \\
\hline 3 & Unsterile soil & 287 & 291 & 152 & 225 & 230 & 258 \\
\hline 4 & Unsterile soil $+\mathrm{SSB}$ & 327 & 363 & 284 & 328 & 248 & 306 \\
\hline
\end{tabular}

Table 13 Release of available silica (ppm) in different soils inoculated with SSB [129]

\begin{tabular}{|c|c|c|c|c|c|c|c|}
\hline \multirow[t]{2}{*}{ S. No. } & \multirow[t]{2}{*}{ Treatments } & \multicolumn{2}{|c|}{ Red soil } & \multicolumn{2}{|c|}{ Clay soil } & \multicolumn{2}{|l|}{ Sand } \\
\hline & & Initial & After 4 weeks & Initial & After 4 weeks & Initial & After 4 weeks \\
\hline 1 & Sterile soil & 105 & 106 & 73 & 75 & 430 & 430 \\
\hline 2 & Sterile soil + SSB & 105 & 135 & 73 & 105 & 430 & 494 \\
\hline 3 & Unsterile soil & 105 & 110 & 73 & 105 & 430 & 453 \\
\hline 4 & Unsterile soil $+\mathrm{SSB}$ & 105 & 145 & 73 & 129 & 430 & 496 \\
\hline
\end{tabular}

Table 14 Influence of SSB inoculation on the yield parameters in Rice [128]

\begin{tabular}{llllll}
\hline Treatments & $\begin{array}{l}\text { No. of } \\
\text { grains per } \\
\text { panicle }\end{array}$ & $\begin{array}{l}1,000 \\
\text { grain } \\
\text { weight } \\
(\mathrm{g})\end{array}$ & $\begin{array}{l}\text { Fully } \\
\text { filled } \\
\text { grains } \\
(\%)\end{array}$ & $\begin{array}{l}\text { Biomass } \\
\left(\mathrm{t} \mathrm{ha}^{-1}\right)\end{array}$ & $\begin{array}{l}\text { Grain } \\
\text { yield } \\
\left(\mathrm{kg} \mathrm{ha}^{-1}\right)\end{array}$ \\
\hline Control & 54 & 22.14 & 76.7 & 10.24 & 3,400 \\
SSB & 62 & 22.84 & 78.1 & 11.27 & 3,800 \\
\hline
\end{tabular}

weight, filled grains, biomass and yield in rice (Table 14). The inoculation of SSB with organosiliceous material like rice straw, husk and husk ash (black char/ash) augmented the grain in rice. Ciobanu found that 'Azotobacterin' and 'Silicabacterin' when applied simultaneously increased the yields of raw cotton up to $34 \%$ [131]. Field inoculation of silicate bacteria enhanced yield of maize, wheat, potato and tomatoes [132]. The beneficial effects of SSB on lucerne and maize were also shown by Vintikova [133].

The solubilized silicon has a larger interaction with other nutrients particularly phosphorus. The $\mathrm{Si}$ in solution renders phosphorus availability to plants reversing its fixation as $\mathrm{Si}$ itself competes for phosphorus fixation sites in the soil. It is to be noted here that to some degree $\mathrm{Si}$ acts as a substitute for $\mathrm{P}$ in plant system. In soil system also application of silicates released more of phosphorus [134].

\section{Conclusion}

The depletion of available Si in soil is an important soilrelated factor that may be closely associated with progressive yield declines experienced in various crops, especially in the tropics. To date the issue of Si nutrition in crop production remains largely unexplored. Identifying and implementing strategic $\mathrm{Si}$ nutrition management strategies may play very well critical role in reversing declining yield trends in crop production. There is need for applied research to quantifying monosilicic and polysilicic acid contents to elaborate optimum Si rate and best time and methods of its application. This is imperative so that the application of Si may be one of the available pathways to improve crop growth and its production in arid or semi arid areas.

Open Access This article is distributed under the terms of the Creative Commons Attribution License which permits any use, distribution, and reproduction in any medium, provided the original author(s) and the source are credited.

\section{References}

1. Cassman KG, De Datta SK, Oik DC, Alcantara J, Samson M, Descalsota J, Dizon M (1995) Yield decline and the nitrogen economy of long-term experiments on continuous, irrigated rice systems in the tropics. In: Lal R, Stewart BA (eds) Soil management experimental basis for sustainability and environmental quality. CRC Publisher, Boca Raton, pp 181-222

2. Anderson DL, Snyder GH, Martin FG (1991) Multi-year response of sugarcane to calcium silicate slag on ever glades Histosols. Agron J 83:870-874

3. Ehrlich HL (1981) Geomicrobiology. Marcel Dekker Inc., New York, p 393

4. Datnoff LE, Snyder GH (2001) Silicon in agriculture. Elsevier Publisher, London

5. Kovda VA (1973) The bases of learning about soils, vol 2. Nauka, Moscow 
6. Matichenkov VV, Calvert DV (2002) Silicon as a beneficial element for sugarcane. J Am Soc Sugarcane Technol 22:21-30

7. Sommer M, Kaczorek D, Kuzyakov Y, Breuer J (2006) Silicon pools and fluxes in soils and landscapes-a review. J Plant Nutr Soil Sci 169:310-329

8. Liang Y, Si J, Romheld V (2005) Silicon uptake and transport is an active process in Cucumis sativus. New Phytol 167:797-804

9. Bazilevich NI (1993) The Biological productivity of North Eurasian ecosystems. RAS Institute of Geography, Nayka, Moscow

10. Matichenkov VV, Bocharnikova EA, Calvert DV, Snyder GH (2000) Comparison study of soil silicon status in sandy soils of south Florida. Soil Crop Sci Soc Fla Proc 59:132-137

11. Matichenkov VV, Ammosova YM, Bocharnikova EA (1997) The method for determination of plant-available silica in soil. Agrochem 1:76-84

12. Takahashi E (1995) Uptake mode and physiological functions of silica. Jpn J Soil Sci Plant Nutr 49:357-360

13. Yoshida S (1975) The physiology of silicon in rice. Food Fertilizer Tech. Centre Technical Bull. No. 25

14. van der Vorm PDJ (1980) Uptake of Si by five plant species as influenced by variations in Si-supply. Plant Soil 56:153-156

15. Marschner H (1995) Mineral nutrition of higher plants. Academic Press, London

16. Ma JF (2003) Function of silicon in higher plants. Prog Mol Subcell Biol 33:127-147

17. Mann S, Ozin GA (1996) Synthesis of inorganic materials with complex form. Nature 382:313-318

18. Jones LHP, Handreck KA (1967) Silica in soil, plants and animals. Adv Agron 19:107-149

19. Ma JF (2009) Silicon uptake and translocation in plants. In: Proceedings of the International Plant Nutrition Colloquium XVI, Department of Plant Sciences, UC Davis. http://www.escholarship.org/uc/item/3pq8p5p0. Accessed April 2013

20. Marschner H (1996) Mineral nutrition of higher plants. Academic Press INC, San Diego

21. Esan K (1953) Plant anatomy. Wiley, New York

22. Takahashi E, Miyake Y (1977) Silica and plant growth. In: Proceedings international seminar on environment and fertility management in intensive agriculture (SEFMIA), Tokyo, Japan, pp 603-611

23. Thiagalingam K, Silva JA, Fox RL (1977) Effect of calcium silicate on yield and nutrient uptake in plant growth on a humic ferriginous latosol. In: Proceedings of Conference on chemistry and fertility of tropical soils. Malaysian society of soil science, Kuallalumpur, Malaysia, pp 149-155

24. Hodson MJ, White PJ, Mead A, Broadley MR (2005) Phylogenetic variation in the silicon composition of plants. Ann Bot 96:1027-1046

25. Nayar PK, Mishra AK, Patnik S (1982) Silica in rice and flooded rice soils. I. Effects of flooding on the extractable silica in soils and its relation with uptake by rice. Oryza 19:34-40

26. Nayar PK, Mishra AK, Patnik S (1982) Silica in rice and flooded rice soils. II. Uptake of silica in relation to growth of rice varieties of different durations grown in an Inceptisol. Oryza 19:88-92

27. Epstein E (1994) The anomaly of silicon in plant biology. Proc Natl Acad Sci USA 91:11-17

28. McCray JM, Mylavarapu R (2010) Sugarcane nutrient management using leaf analysis. Florida Cooperative Extension Service Fact Sheet SS-AGR-335. UF/IFAS Electronic Data Information Source (EDIS) Database. University of Florida, Gainesville, FL. http://edis.ifas.ufl.edu/ag345. Accessed 22 July 2011
29. McCray JM, Ji S, Powell G, Montes G, Perdomo R, Luo Y (2010) Boundary lines used to determine sugarcane production limits at leaf nutrient concentrations less than optimum. Comm Soil Sci Plant Anal 41:606-622

30. Russell EW (1973) Soil conditions and plant growth. Longman, London, p 756

31. Gallo JR, Furlani PR, Bataglia OC, Hiroce R (1974) Silicon content in grass and forage crops. Cienciae Cult 26:282-293

32. Ishizuka Y (1971) Physiology of the rice plant. Adv Agron 23:241-315

33. Jones LHP, Handreck KA (1967) Silica in soils, plants and animals. Adv Agron 19:107-149

34. Powell JJ, McNaughton SA, Jugdaohsingh R, Anderson SHC, Dear J, Khot F, Mowatt L, Gleason KL, Sykes M, Thompson RPH, Bolton-Smith C, Hodson MJ (2005) A provisional database for the silicon content of foods in the United Kingdom. Br J Nutr 94:804-812

35. Pennington JAT (1991) Silicon in food and diets. Food Addit Contam 8:97-118

36. Gascho GJ (2001) Silicon sources for agriculture. In: Datnoff LE, Snyder GH, Korndorfer GH (eds) Silicon in agriculture. Elsevier, Amsterdam, pp 197-207

37. Liang YC, Chen Q, Liu Q, Zhang WH, Ding RX (2003) Exogenous silicon $(\mathrm{Si})$ increases antioxidant enzyme activity and reduces lipid peroxidationin roots of salt-stressed barley (Hordeum vulgare L.). J Plant Physiol 160:1157-1164

38. Inanaga S, Okasaka A, Tanaka S (1995) Does silicon exist in association with organic compounds in rice plant? Japan J Soil Sci Plant Nutr 11:111-117

39. Datnoff LE, Elmer WH, Huber DM (2005) Silicon and plant disease. In: Datnoff LE (ed) Mineral nutrition and plant disease. American Phytopathological Society, St. Paul

40. Winslow MD (1992) Silicon, disease resistance and yield of rice genotypes under upland cultural conditions. Crop Sci 32:208-213

41. Datnoff LE, Snyder GH, Deran CW (1992) Influence of silicon fertilizer grade on blast and brown spot development in rice yields. Plant Dis 76:1182-1184

42. Elawad SH, Green VE (1979) Silicon and the rice plant environment: a review of recent research. II Riso 28:235-253

43. Dean JL, Todd EH (1979) Sugar rust in Florida. Sugar J 42:10

44. Raid RN, Annderson DL, Ulloa MF (1991) Influence of cultivar and soil amendment with calcium silicate slag on foliar disease development and yield of sugarcane. Florida Agric Exp Stn J Ser N R-01689

45. Grundnofer H (1994) Eifluss von silikataufnahme und einlagerung auf den befall der rebe mit echtem mehltau. Diss 114:102-114

46. Bowen P, Menzies J, Ehret D, Samuel L, Glass ADM (1992) Soluble silicon sprays inhibit powdery mildew development on grape leaves. J Am Soc Hortic Sci 117:906-912

47. Adatia MH, Besford RT (1986) The effects of silicon on cucumber plants grown in recirculating nutrient solution. Ann Bot 58:343-351

48. Cherif M, Belanger RR (1992) Use of potassium silicate amendments in recirculating nutrient solution to suppress Pythium ultimum on long English cucumber. Plant Dis 76:1008-1011

49. Carver TLW, Zeyen RJ, Ahlstrand GG (1987) The relation between insoluble silicon and success or failure of attempted penetration by powdery mildew (Erysiphe graminis) germlings on barley. Physiol Plant Pathol 31:133-148

50. Jiang D, Zeyen RJ, Russo V (1989) Silicon enhances resistance of barley to powdery mildew (Erusiphe graminis $f$. sp. hordei). Phytopathology 79:1198 
51. Leusch HJ, Buchenaner H (1989) Effect of soil treatments with silica-rich lime fertilizers and sodium silicate on the incidence of wheat by Erysiphe graminis and Septoria nodorum depending on the form of N-fertilizer. J Plant Dis Prot 96:154-172

52. Dann EK, Muir S (2002) Peas grown in media with elevated plant-available silicon levels have higher activities of chitinases and $\beta-1,3$-glucanase, are less susceptible to a fungal leaf spot pathogen and accumulate more foliar silicon. Aust Plant Pathol 31:9-13

53. Brecht ML, Datnoff LE, Kucharek T, Nagata R (2001) Effect of silicon and chlorothalonil on suppression of gray leaf spot in St. Augustinegrass. Phytopathology 91:S11

54. Datnoff LE, Rutherford BA (2003) Accumulation of silicon by bermudagrass to enhance disease suppression of leaf spot and melting out. USGA Turfgrass Environ Res Online 2(18):1-6

55. Cherf M, Menzies JG, Ehret DL, Bopgdanoff C, Belanger RR (1994) Yield of cucumber infected with Pythium aphanidermatum when grown with soluble silicon. Hortic Sci 29:896-897

56. Sawant AS, Patil VH, Savant NK (1994) Rice hull ash applied to seebold reduces dead hearts in transplanted rice. Int Rice Res Notes 19(4):21-22

57. Maxwell FG, Jenkins JN, Parrott WL (1972) Resistance of plants to insects. Adv Agron 24:187-265

58. Sujatha G, Reddy GPV, Murthy MMK (1987) Effect of certain biochemical factors on expression of resistance of rice varities to brown plant hopper (Nilaparvata lugens Stal). J Res APAU 15(2):124-128

59. Salim M, Saxena RC (1992) Aluminum stresses and varietal resistance: effects on white backed plant hopper. Crop Sci 32:212-219

60. Savant AS, Patit VH, Savant NK (1994) Rice hull ash applied to seedbed reduces dead hearts in transported rice. Int Rice Res Notes 19:21-22

61. Wadham MD, Parry PW (1981) The silicon content of Oryza sativa $\mathrm{L}$. and its effect on the grazing behaviour of Agriolimax reticulates. Muller Ann Bot 48:399-402

62. Tanaka A, Park YD (1966) Significance of the absorption and distribution of silica in the rice plant. Soil Sci 12:191-195

63. Gomes FB, Mores JC, de Santos dos CD, Goussain MM (2005) Resistance induction in wheat plants by silicon and aphids. Sci Agric 62:547-551

64. Setamou M, Schulthess F, Bosque-Perez NA, Thomas-Odjo A (1993) Effect of plant nitrogen and silicon on the biomocs of Sesamia calamistics. Bull Entomol Res 83:405-411

65. Carvalho SP, Oraes JC, Carvalho JG (1999) Efeito do silicio na Resistencia do sorgo (Sorghum bicolor) ao pulgao verde Schizaphis graminum(Rond)(Hemiptera: Aphododae). Anais da Sociedade Entomologica Do Brasil 28:505-510

66. Goussain MM (2001) Efeito da aplicacao do silicio em plantas de milho no desenvolvimento bilogiico da lagarta-do-cartucho Spodoptera frugiperda (J.M.Smith) e do pulgao-da-folha Rhopalosiphum maidis(Fitch,1856) (Hemiptera:Aphididae). Lavras: UFLA, pp 63

67. Kvedaras OL, Keeping MG, Goebel R, Byrne M (2005) Effects of silicon on the African Stalk Borer, Eldana saccharina (Lepidoptera: Pyralidae) in Sugarcane. Proc S Afr Sug Technol Ass 79:359-362

68. Elawad SH, Allen LH Jr, Gascho GJ (1985) Influence of UV-B radiation and soluble silicates on the growth and nutrient concentration of sugarcane. Proc Soil Crop Sci Soc Fla 44:134-141

69. Young S, Kyong MK, Sang CL, Jong CP (1996) Effects of lime and silica fertilizer application on grape cracking. J Agric Sci Soil Fert 38:410-415

70. Chang SJ, Tzeng DD, Li CC (2002) Effect of silicon nutrient on bacterial blight resistance of rice (Oryza sativa L.). In: Abstract of second silicon in agriculture conference, pp 31-33
71. Hattori T, Inanaga S, Araki H, An P, Mortia S, Luxova M, Lux A (2005) Application of silicon enhanced drought tolerance in Sorghum bicolor. Physio Plantarum 123:459-466

72. Marschner H, Oberle H, Cakmar I, Romheld V (1990) Growth enhancement by silicon in cucumber (Cucumis sativus) plants depends on imbalance in phophorus and zinc supply. In: Van Bensichem ML (ed) Plant nutrition-physiology and application, Kluwer Academic Publication, Dordrecht, pp 241-249

73. Natoh T, Kairusmee P, Takahashi E (1986) Salt-induced damage to rice plants and alleviation effect of silicate. Soil Sci Plant Nutr 32:295-304

74. Zaheer AhmadRSH, Ismail S (1992) Role of silicon in $s$ alt tolerance of wheat (Triticum aestivum. L.). Plant Sci 85:43-50

75. Bradbury M, Ahmad R (1990) The effect of silicon on the growth of Prosopis juliflora growing in saline soil. Plant Soil 125:71-74

76. Horst WJ, Marschner H (1978) Effect of silicon and manganese tolerance of bean plants (Phaseolus vulgaris L.). Plant Soil 50:287-303

77. Horiguchi T (1988) Effect of silicon on alleviation of Mn toxicity of rice plants. Soil Sci Plant Nutr 34:65-73

78. Li YC, Alva AK, Summer ME (1989) Response of cotton cultivars to aluminium in solutions with varying silicon concentrations. J Plant Nutr 12:881-892

79. Fox RL, Silva JA, Younge OR, Plucknett DL, Sherman GD (1967) Soil and plant silicon and silicate response by sugarcane. Soil Sci Soc Am 31:775-779

80. Rizwan M, Meunier JD, Miche H, Keller C (2012) Effect of silicon on reducing cadmium toxicity in durum wheat (Triticum turgidum L. cv. Claudio W.) grown in a soil with aged contamination. J Hazard Mater 209-210:326-334

81. Ma JF (2004) Role of silicon in enhancing the resistance of plants to biotic and abiotic stresses. Soil Sci Plant Nutr 50(1):11-18

82. Epstein E (1999) Silicon. Ann Rev Plant Physiol Mol Biol 50:641-664

83. Wong YC, Heits A, Ville JD (1972) Foliar symptoms of silicon deficiency in the sugarcane plant. Proc Congr Int Soc Sugarcane Technol 14:766-776

84. Kaya C, Tuna L, Higgs D (2006) Effect of silicon on plant growth and mineral nutrition of maize grown under water-stress conditions. J Plant Nutr 29:1469-1480

85. Lux A, Luxova M, Hattori T, Inanaga S, Sugimoto Y (2002) Silicification in sorghum (Sorghum bicolor) cultivars with different drought tolerance. Physiol Plantarum 115:87-92

86. Klepper B (1991) Root-shoot relationships. In: Waisel Y, Eshel A, Kafkafi U (eds) Plant roots: the hidden half. Marcel Dekker, New York, pp 265-286

87. Tisdale SL, Nelson WL, Beaton JD (1985) Soil fertility and fertilizers. MacMillan Publisher, New York, p 754

88. Takahashi E, Miyake Y (1982) The effect of silicon on the growth of cucumber plant. In: Proceedings of 9th international plant nutr Collog Warwick Univ, UK, pp 669

89. Ma J, Takahashi E (1990) Effect of silicon on the growth and phosphorus uptake of rice. Plant Soil 126:115-119

90. Gong HJ, Chen KM, Chen GC, Wang SM, Zhang CL (2003) Effect of silicon on growth of wheat under drought. J Plant Nutr 26(5):1055-1063

91. Padmaja P, Verghese EJ (1972) Effect of Ca, Mg, and Si on the uptake of plant nutrients and availability of straw and grain of paddy. Agric Res J Kerala 10:100-105

92. Ota M, Kobayashi H, Kawaguchi Y (1957) Effect of slag on paddy rice. 2. Influence of different nitrogen and slag levels on growth and composition of rice plant. Soil Plant Food 3:104-107 
93. Dong CT, Liu ZG, Zou BJ, Zhu C, Zhang CL, Liang W (1981) (1) Study on the nutrition of rice. (2). Effect of zinc and Silicon in increasing rice yield. Lianing Agric Sci 4:13-18

94. Gerami M, Fallah A, Khatami moghadam MR (2012) Study of potassium and sodium silicate on the morphological and chlorophyll content on the rice plant in pot experiment (Oryza sativa L.). Intl J Agric Crop Sci 4(10):658-661

95. Singh K, Singh R, Singh JP, Singh Y, Singh KK (2006) Effect of level and time of silicon application on growth, yield and its uptake by rice (Oryza sativa). Ind J Agric Sci 76(7):410-413

96. Savant NK, Snyder GH, Datnoff LE (1997) Silicon management and sustainable rice production. Adv Agron 58:151-199

97. Silva JA (1971) Possible mechanisms of crop response to silicate applications. Proc Int Symp Soil Fert Eval 1:805-814

98. Elawad SH, Gascho GJ, Street JJ (1982) Response of sugarcane to silicate source and rate. I. Growth and yield. Agron J 74:481-484

99. Bocharnikova EA (1996) The study of direct silicon effect on root demographics of some cereals. In: Proceedings of the 5th symposium of the international society of root research. Root demographics and their efficiencies in sustainable agriculture, grasslands, and forest ecosystems, Madrea Conference ConterClenson, South Carolina, 14-18 July

100. Matichenkov VV (1996) The silicon fertilizer effect of root cell growth of barley. In: Abstract in the 5th symposium of the international society of root research, Clemson, SC, USA, pp 110

101. Kudinova LI (1974) The effect of silicon on weight of plant barley. Sov Soil Sci 6:39-41

102. Yamaguchi T, Tsuno Y, Nakano J, Mano P (1995) Relationship between root respiration and silica: calcium ratio and ammonium concentration in bleeding sap from stem in rice plants during the ripening stage. Japan. J Crop Sci 64:529-536

103. Matichenkov VV, Calvert DV, Snyder GH (1999) Silicon fertilizers for citrus in Florida. Proc Fla State Hortic Soc 112:5-8

104. Matichenkov VV, Calvert DV, Snyder GH (2000) Effect of Si fertilization on growth and P nutrition of Bahiagrass. Proc Soil Crop Sci Soc Fla 60:30-36

105. Korndörfer GH, Lepsch I (2001) Effect of silicon on plant growth and crop yield. In: Datnoff LE, Snyder GH, Korndorfer GH (eds) Silicon in agriculture. Studies in plant science. Elsevier, Amsterdam, pp 133-147

106. Mukhtar A, Asif M, Goyal A (2012) Silicon the non-essential beneficial plant nutrient to enhanced drought tolerance in wheat crop plant. In: Goyal A (ed). http://www.intechopen.com/ books/crop-plant/silicon-the-non-essential-beneficial-plantnutrientto-enhanced-drought-tolerance-in-wheat. Accessed May 2013

107. Ahmed M, Hassen FU, Qadeer U, Aslam MA (2011) Silicon application and drought tolerance mechanism of sorghum. Afr J Agric Res 6(3):594-607

108. Mukkram AT, Tariq RahmatullahA, Ashraf M, Shamsa K, Maqsood MA (2006) Beneficial effects of silicon in wheat (Triticum aestivum L.) under salinity stress. Pak J Bot 38(5):1715-1722

109. Abro SA, Qureshi R, Soomro FM, Ahmed AM, Jakhar GS (2009) Effects of silicon levels on growth and yield of wheat in silty loam soil. Pak J Bot 41(3):1385-1390

110. Singh K, Singh R, Singh JP, Singh Y, Singh KK (2006) Effect of level and time of silicon application on growth, yield and its uptake by rice (Oryza sativa). Ind J Agric Sci 76(7):410-413

111. Raid RN, Anderson DL, Ulloa MF (1992) Influence of cultivar and amendment of soil with calcium silicate slag on foliar disease development and yield of sugar-cane. Crop Prot 11:84-88

112. Hattori T, Inanaga S, Araki H, An P, Mortia S, Luxova M, Lux A (2005) Application of silicon enhanced drought tolerance in Sorghum bicolor. Physiol Plantarum 123:459-466
113. Anderson DL, Jones DB, Snyder GH (1987) Response of a ricesugarcane rotation to calcium silicate slag on everglades Histosols. Agron J 79:531-535

114. Datta NP, Shinde JE (1985) Yield and nutrition of rice under upland and waterlogged conditions. Effect of nitrogen, phosphorus and silica. J Indian Soc Soil Sci 33:53-60

115. Okamoto Y (1969) Effect of silicic acid upon rice plants (9) On growth under high and low temperature of the culture solution (10) On growth under high and low air temperatures. Proc Crop Sci Soc Jpn 38:743-752

116. Sadanandan AK, Verghese EJ (1969) Role of silicate in the uptake of nutrients by rice plants in the laterite soils of Kerala. Agric Res J Kerala 7:91-96

117. Islam A, Saha RC (1969) Effect of silicon on the chemical composition of rice plants. Plant Soil 30:446-458

118. Savant NK, Snyder GH, Datnoff LE (1997) Silicon management and sustainable rice production. Adv Agron 58:151-199

119. Aleshin EP, Aleshin NE, Avakian AR (1978) The effect of various nutrition and gibberillins on $\mathrm{SiO}_{2}$ content in hulls of rice. Agrochem 7:64-68

120. IRRI (1993a) Rice research in a time change: IRRI's MediumTerm Plan, 1994-1998. International Rice Research Institute, Los Banos, Philippines

121. Matichenkov VV (1990) Amorphous oxide of silicon in soddy podzolic soil and its influence on plants. Autoref Diss Canada Moscow State University, Moscow

122. Miyake Y (1993) On the environmental condition and nitrogen source to appearance of silicon deficiency of the tomato plant. Sci Rep Fac Agric (Okayama Univ) 81:27-35

123. Taranovskaia VG (1939) The silicication of subtropic greenhouse and plantations. Sov Subtrop 7:32-37

124. Tripathi DK, Mishra S, Chauhan DK, Tiwari SP, Kumar C (2013) Typological and frequency based study of opaline silica (phytolith) deposition in two common Indian sorghum. Proc Natl Acad Sci India Sec B 83(1):97-104

125. Chookietwattana K, Maneewan K (2012) Screening efficient halotolerant phosphate solubilising bacteria and its effect on promoting plant growth under saline conditions. World Appl Sci J 16(8):1110-1117

126. Kauchebagh SB, Mirshekaw B, Farahvash F (2012) Improvement of corn yield by seed biofertilizer and urea application. World Appl Sci J 16(9):1239-1242

127. Lauwers AM, Heinen W (1974) Biodegradation and utilization of silica and qurtz. Arch Microbiol 95:67-78

128. Avakyan ZA, Pavavarova TA, Karavako GI (1986) Properties of a new species, Bacillus mucilaginous. Microbiol 55:477-482

129. Muralikannan N (1996) Biodissolution of silicate, phosphate and potassium by silicate solubilizing bacteria in rice ecosystem. M Sc (Ag) thesis submitted to Tamil Nadu Agricultural University, Coimbatore, pp 125

130. Muralikannan N, Anthomiraj S (1998) Occurrence of silicate solublising bacteria in rice ecosystem. Madras Agric $\mathrm{J}$ 85(1):47-50

131. Ciobanu I (1961) Investigation on the efficiency on for biocontrol of Macrophomina phaseolina bacterial fertilizers applied to cotton. J Biol Cent Exp Control 8:41-44

132. Aleksandrov VG (1958) Organo-mineral fertilizers and silica bacteria. Dokl Akad-S Kh Nauk 7:43-48

133. Vintikova H (1964) A contribution to study on efficiency of silicate bacteria. Rostl Vyr 37:1219-1228

134. Chinnasami KN, Chandrasekaran S (1978) Silica status in certain soils of Tamil Nadu. Madras Agric J 65:743-746 